\title{
Selective Mono-methylation of Arylacetonitriles and Methyl Arylacetates by Dimethyl Carbonate
}

\author{
Maurizio Selva, Carlos Alberto Marques and Pietro Tundo* \\ Dipartimento di Ścienze Ambientali dell'Università di Venezia, Calle Larga S. Marta, 2137-30123, \\ Venezia, Italy
}

Both arylacetonitriles and methyl arylacetates react with dimethyl carbonate (DMC) (20 molar excess) at $180-200^{\circ} \mathrm{C}$ in the presence of $\mathrm{K}_{2} \mathrm{CO}_{3}$ to produce monomethylated 2-arylpropionitriles and methyl 2-arylpropionates, respectively, with a selectivity $>99.5 \%$. The reaction, with wide application, proceeds by DMC acting as a methoxycarbonylating agent towards the $A r \mathrm{CH}^{-} \mathrm{X}_{\text {anion }}$ $\left(\mathrm{X}=\mathrm{CN}, \mathrm{CO}_{2} \mathrm{Me}\right)$ and as a methylating agent to $\mathrm{ArC}^{-}\left(\mathrm{CO}_{2} \mathrm{Me}\right) \mathrm{X}$. DMC also proved to be the best solvent for such reactions.

Direct base-promoted mono-alkylation of methylene-active compounds, is not easy ${ }^{1}$ since the reaction usually proceeds to dialkylation, especially so in the case of methylation. Essentially, this is because of the small difference in acidity between the reagent and the monoalkylated compound: the $\mathrm{p} K_{\mathrm{a}}$ values of compounds 1 and 2 are comparable as illustrated for the arylacetonitriles in eqn. (1).

$$
\begin{aligned}
& \mathrm{ArCH}(\mathrm{R}) \mathrm{CN}+\mathrm{B} \rightleftharpoons \mathrm{ArC}(\mathrm{R}) \mathrm{CN}+\mathrm{BH}^{+} \\
& \quad \mathbf{R}=\mathrm{H} \\
& \mathbf{2} \mathrm{R} \neq \mathrm{H}
\end{aligned}
$$

Since the monomethylated arylacetonitriles $2(R=M e)$ are important precursors of 2-arylpropionic acids, the well known anti-inflammatory drugs, compound 1 was treated with a variety of alkylating agents (e.g. alkyl halides, dialkyl sulfates) with the hope of inducing monomethylation. ${ }^{2}$ Even under phase-transfer catalysis (PTC) conditions, however, highly selective monomethylation was elusive. ${ }^{3}$

Of the new methods for alkylation under safe conditions and with non-toxic reagents, ${ }^{4}$ gas-liquid phase-transfer catalysis (GL-PTC) $\dagger$ conditions with dimethyl carbonate (DMC) as a methylating agent is of particular interest. Under such conditions, operating in a catalytic bed composed of $\mathrm{K}_{2} \mathrm{CO}_{3}$ and polyethylene glycols as PT catalysts, DMC methylated phenols, ${ }^{6}$ amines, ${ }^{7}$ phenylacetonitrile and ( $p$-isobutylphenyl)acetonitrile with high selectivity. ${ }^{8}$

Interestingly, methylation with non-toxic DMC (not now prepared from phosgene but by oxidative carbonylation of methanol) ${ }^{9}$ produced no waste, the base being catalytic, the methanol recyclable and the $\mathrm{CO}_{2}$ involving no disposal problems. Only those compounds having a relatively high vapour tension, however, react under such conditions.

We report here the highly selective batchwise reaction of arylacetonitriles and arylacetic esters with DMC.

\section{Results}

The reactions, carried out in an autoclave, are reported in detail in the Experimental section whilst the results for the methylation of phenylacetonitrile by different methods are

$\uparrow$ GL-PTC is a continuous-flow procedure for carrying out organic reactions: gaseous reagents are allowed to flow through molten phasetransfer catalysts (e.g. polyethylene glycols, PEGs, onium salts, etc.) supported on a solid. The catalytic bed is fitted into a plug-flow reactor, thermostatted at the reaction temperature. In the case of DMC, methylation requires the presence of a base as co-catalyst. ${ }^{5}$ recorded in Table 1. Iodomethane was the methylating agent for extractive alkylation ${ }^{10}$ and PTC. ${ }^{11}$

Highly selective monomethylation is observed with DMC under both GL-PTC (Table 1, entry 3) and batch conditions (entries 4-6). With DMC as solvent at $180^{\circ} \mathrm{C}$ in the presence of $\mathrm{K}_{2} \mathrm{CO}_{3}$, phenylacetonitrile $1 \mathrm{a}$ is converted into 2-phenylpropionitrile 3a [see eqn. (2)]. No PT catalyst is necessary

$$
\begin{aligned}
& \mathrm{ArCH}_{2} \mathrm{CN}+\mathrm{MeOCO}_{2} \mathrm{Me} \stackrel{\mathrm{K}_{2} \mathrm{CO}_{3}}{\longrightarrow} \\
& 1 \\
& \mathrm{ArCH}(\mathrm{Me}) \mathrm{CN}+\mathrm{MeOH}+\mathrm{CO}_{2} \\
& \mathbf{3} \equiv \mathbf{2}(\mathrm{R}=\mathrm{Me})
\end{aligned}
$$

under such batch conditions. After $3.75 \mathrm{~h}$ at $180^{\circ} \mathrm{C}$ monomethylation was complete, the product being obtained with $>99.5 \%$ selectivity (Table 1 , entry 6 ). Further methylation to 2-phenylisobutyronitrile was very slow under the conditions reported in Table 1 , entry $6,70 \%$ conversion taking place only after $25 \mathrm{~h}$.

Reaction (2) is temperature sensitive since at $160^{\circ} \mathrm{C}$ only a $67 \%$ conversion was observed (Table 1 , entry 5 ) after $18 \mathrm{~h}$.

Table 2 provides evidence that the reaction was promoted by base: results for the use of a catalytic quantity $(0.05 \mathrm{~mol}$ equiv.) of a variety of carbonates are listed. $\ddagger$ The reaction rate is clearly related to the solubility of the carbonates, the effect being one of promotion with $\mathrm{Cs}_{2} \mathrm{CO}_{3}$ and depression with $\mathrm{Li}_{2} \mathrm{CO}_{3}$; the selectivity, however, always remained high. Although, under similar conditions, stronger bases (phosphazene derivatives $\mathrm{P}_{1}$ and $\mathrm{P}_{4},{ }^{12}$ entries 6 and 7) also promoted the reaction, the selectivity was lower.

Table 3 lists the results for reactions in a variety of solvents for which either 5 or 18 molar equiv. (with respect to the substrate) of DMC were used. These reactions showed no substantial improvement over those in which only DMC was present. In fact both DMF and MeI lowered the selectivity (entries 2 and 6).

All the arylacetonitriles used in this work (see Table 4). yielded monomethyl derivatives in reactions carried out at $180^{\circ} \mathrm{C}$. Under the conditions of Table 1 , entry 6 , at complete conversion selectivity was always $>99.5 \%$, only the monomethyl derivative being present.§

$\ddagger$ Although used in catalytic amounts in entries 2-5, alkaline carbonates are still present as solids in the reaction mixture. The slower reaction rate of entry of Table 2 compared to entry 6 of Table 1 (both reactions being carried out in the presence of insoluble $\mathrm{K}_{2} \mathrm{CO}_{3}$ ) may be attributed to the buffering effect of the carbonate salt on the $\mathrm{CO}_{2}$ produced in the reaction (2).

$\S$ At complete conversion, selectivity $>99.5 \%$ means that the dimethyl derivative is $<0.5 \%$. 
Table 1 Methylation of phenylacetonitrile carried out by different methylating agents and under different conditions

\begin{tabular}{|c|c|c|c|c|c|c|c|c|}
\hline Entry & $\begin{array}{l}\text { Reaction } \\
\text { conditions }\end{array}$ & $\begin{array}{l}\text { Methylating } \\
\text { agent }\end{array}$ & $\begin{array}{l}\text { Ratio of } \\
\text { methylating } \\
\text { agent to } \\
\text { substrate } \\
(\mathrm{mol} / \mathrm{mol})\end{array}$ & $\begin{array}{l}\text { Phase-transfer } \\
\text { catalyst }\end{array}$ & $T /{ }^{\circ} \mathrm{C}$ & $\begin{array}{l}\text { Reaction } \\
\text { time }(t / \mathrm{h})\end{array}$ & $\begin{array}{l}\text { Conv'n. } \\
(\%)\end{array}$ & $\begin{array}{l}\text { Selectivity }{ }^{a} \\
(\%)\end{array}$ \\
\hline 1 & $\begin{array}{l}\text { Extractive } \\
\text { alkylation }^{b}\end{array}$ & MeI & 10 & $\mathrm{Bu} \mathrm{N}^{+} \mathrm{OH}^{-}$ & Room temn & 017 & & \\
\hline 2 & PTC $^{c}$ & MeI & 1.3 & $(\mathrm{EtO})_{2} \mathrm{P}(\mathrm{O}) \mathrm{CH}_{2} \mathrm{~S}(\mathrm{O}) \mathrm{Ph}$ & Room temp. & $\begin{array}{l}0.17 \\
2.0\end{array}$ & $\begin{array}{l}00 \\
94\end{array}$ & $\begin{array}{l}84 \\
71\end{array}$ \\
\hline 3 & GL-PTC ${ }^{d}$ & DMC & 4.0 & PEG $6000^{e}$ & 180 & & $98^{f}$ & 99 \\
\hline 4 & Batch $^{g}$ & DMC & 18.0 & - & 130 & 4.0 & \multicolumn{2}{|c|}{ No reaction } \\
\hline 5 & Batch $^{g}$ & DMC & 18.0 & - & 160 & 18.0 & $67^{h}$ & 100 \\
\hline 6 & Batch $^{9}$ & DMC & 18.0 & - & 180 & 3.75 & $100^{i}$ & $>99.5$ \\
\hline
\end{tabular}

${ }^{a}$ Selectivity in monomethylation is defined as $\left[(\mathrm{mol}\right.$ of $\mathrm{PhCH}(\mathrm{Me}) \mathrm{CN}) /\left(\mathrm{mol}\right.$ of $\mathrm{PhCH}(\mathrm{Me}) \mathrm{CN}+\operatorname{mol}$ of $\left.\left.\mathrm{PhC}(\mathrm{Me})_{2} \mathrm{CN}\right)\right] \times 100 .{ }^{b} \mathrm{From}$ ref. 10 ' Phase-transfer catalysis; from ref. $11 .{ }^{d}$ Gas-liquid phase-transfer catalysis. ${ }^{e}$ Catalytic bed consisted $5 \%$ wt of $\mathrm{K}_{2} \mathrm{CO}_{3}$ (as co-catalyst) and $5 \%$ wt of PEG (polyethylene glycol) 6000 supported on Corundum spheres (for further details, see ref. 8). ${ }^{f} 1 \%$ of PhC(Me) ${ }_{2} \mathrm{CN}$ was detected. ${ }^{g}$ Reactions carried out in autoclave and in the presence of a 2 equiv. of $\mathrm{K}_{2} \mathrm{CO}_{3},{ }^{h} 41 \%$ of $\mathrm{PhCH}(\mathrm{Me}) \mathrm{CN}$ was present, the remainder $(26 \%)$ being reaction intermediates (GC analysis). ${ }^{i}$ At complete conversion, detectable products, except for $\mathrm{PhCH}(\mathrm{Me}) \mathrm{CN}$, were less than $1 \%$ in total.

Table 2 Methylation of phenylacetonitrile with DMC using different bases in catalytic amounts ${ }^{a}$

\begin{tabular}{|c|c|c|c|c|c|c|}
\hline Entry & Base & $\begin{array}{l}\text { Solubility } \\
\left(s / \mathrm{g} \mathrm{dm}^{-3}\right)^{d}\end{array}$ & $\begin{array}{l}\text { Ratio of } \\
\text { substrate } \\
\text { to base } \\
(\mathrm{mol} / \mathrm{mol})\end{array}$ & $\begin{array}{l}\text { Reaction } \\
\text { time }(t / \mathrm{h})\end{array}$ & $\begin{array}{l}\text { Conv'n. }{ }^{b} \\
(\%)\end{array}$ & $\begin{array}{l}\text { Selectivity }{ }^{c} \\
(\%)\end{array}$ \\
\hline 1 & No base & - & 20 & 5.0 & 0 & - \\
\hline 2 & $\mathrm{Li}_{2} \mathrm{CO}_{3}$ & 0.20 & 20 & 7.25 & 5 & $>99.5$ \\
\hline 3 & $\mathrm{Na}_{2} \mathrm{CO}_{3}$ & 0.26 & 20 & 8.75 & 89 & $>99.5$ \\
\hline 4 & $\mathrm{~K}_{2} \mathrm{CO}_{3}$ & 0.58 & 20 & 7.50 & 98 & $>99.5$ \\
\hline 5 & $\mathrm{Cs}_{2} \mathrm{CO}_{3}$ & 0.64 & 20 & 5.75 & 100 & $>99.5$ \\
\hline 6 & Phosphazene $\mathrm{P}_{1}{ }^{e}$ & & 10 & 7.75 & 99 & 82.0 \\
\hline 7 & Phosphazene $\mathrm{P}_{4} \mathrm{~s}$ & & 10 & 5.0 & 97 & $<1$ \\
\hline
\end{tabular}

${ }^{a}$ All reactions were carried out in an autoclave at $180^{\circ} \mathrm{C}$ with a $\mathrm{PhCH}_{2} \mathrm{CN}-\mathrm{DMC} 1: 18$ molar ratio. ${ }^{b}$ Conversion was determined by GC. At complete conversion, detectable products, except for $\mathrm{PhCH}(\mathrm{Me}) \mathrm{CN}$, were always less than $1 \%$ in total. ${ }^{c}$ Selectivity is defined as: $[(\mathrm{mol}$ of $\mathrm{PhCH}(\mathrm{Me}) \mathrm{CN}) /(\mathrm{mol}$ of $\mathrm{PhCH}(\mathrm{Me}) \mathrm{CN}+\mathrm{mol}$ of $\left.\left.\mathrm{PhC}(\mathrm{Me})_{2} \mathrm{CN}\right)\right] \times 100 .{ }^{d}$ Solubility is referred to DMC. ${ }^{e}$ The base, tert-butyliminotris(dimethylamino)phosphorane (ref. 13, Fluka n. 79408) was completely soluble in DMC. ${ }^{f}$ The base 1-tert-butyl-4,4,4-tris(dimethylamino)-2,2,2-bis[tris(dimethyl-

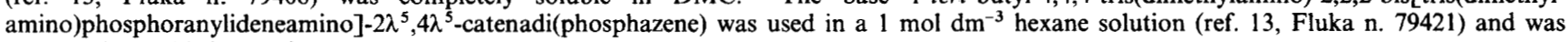
completely soluble in DMC.

Table 3 Methylation of phenylacetonitrile in the presence of different solvents ${ }^{a}$

\begin{tabular}{llllllll}
\hline Entry & Solvent & $\begin{array}{l}\text { Ratio of } \\
\text { solvent to } \\
\text { substrate } \\
(\mathrm{v} / \mathrm{v})\end{array}$ & $\begin{array}{l}\text { Ratio of } \\
\text { DMC to } \\
\text { substrate } \\
(\mathrm{mol} / \mathrm{mol})\end{array}$ & $\begin{array}{l}\text { Conv'n. } \\
(\%)\end{array}$ & $\begin{array}{l}\text { Reaction } \\
\text { time }(t / \mathrm{h})\end{array}$ & $\begin{array}{l}\text { Selectivity }^{b} \\
(\%)\end{array}$ \\
\hline 1 & & & 18 & 100 & 3.75 & $>99.5^{c}$ \\
2 & Methanol & 10 & $18^{d}$ & 100 & 3.75 & 96 \\
3 & Methanol & 10 & 18 & 20 & 5.5 & $>99.5$ \\
4 & DMF & 10 & 5 & 96 & 3.5 & $>99.5$ \\
5 & DMF & 10.7 & $18^{e}$ & 75 & 3.75 & 90 \\
6 & Cyclohexane & 10 & 5 & 25 & 6.0 & $>99.5$ \\
\hline
\end{tabular}

${ }^{a}$ All reactions were carried out at $180^{\circ} \mathrm{C}$ in an autoclave using DMC as alkylating agent in the presence of $\mathrm{K}_{2} \mathrm{CO}_{3}$ ( 2 equiv. with respect to substrate). ${ }^{b}$ Selectivity is defined as: $\left[(\mathrm{mol}\right.$ of $\mathrm{PhCH}(\mathrm{Me}) \mathrm{CN}) /\left(\mathrm{mol}\right.$ of $\mathrm{PhCH}(\mathrm{Me}) \mathrm{CN}+\mathrm{mol}$ of $\left.\left.\mathrm{PhC}(\mathrm{Me}){ }_{2} \mathrm{CN}\right)\right] \times 100 .{ }^{c}$ From entry 6, Table $1 .{ }^{d}$ The reaction was carried out in the presence of MeI ( 0.05 equiv. with respect to the substrate). ${ }^{e}$ The reaction was carried out in the presence of MeI ( 2.5 equiv. with respect to substrate).

Table 5 lists the results for the reactions of arylacetic esters with $\mathrm{DMC}^{13}$ [see eqn. (3)]; these occurred only at temperatures in the range $200-220^{\circ} \mathrm{C}$, but as with the nitriles, the reactions

$$
\begin{aligned}
& \underset{4}{\mathrm{ArCH}_{2} \mathrm{CO}_{2} \mathrm{Me}}+\mathrm{Me}_{2} \mathrm{CO}_{3} \stackrel{\mathrm{K}_{2} \mathrm{CO}_{3}}{\longrightarrow} \\
& \mathrm{ArCH}(\mathrm{Me}) \mathrm{CO}_{2} \mathrm{Me}+\mathrm{CO}_{2}+\mathrm{MeOH}
\end{aligned}
$$

are highly selective towards monomethylation. Although diethyl carbonate (DEC) also induces selective monoalkylation with both arylacetonitriles and arylacetic esters the reaction rates are slower than the corresponding ones for DMC (see Table 6).

In order to investigate the reasons for this high selectivity, compounds 6a and 7a (synthesized independently) were allowed to react with DEC, under specific conditions (Table 1, entry 6); the reactions illustrated in Scheme 1 were observed. The 
Table 4 Reactions of dimethyl carbonate with arylacetonitriles ${ }^{a}$

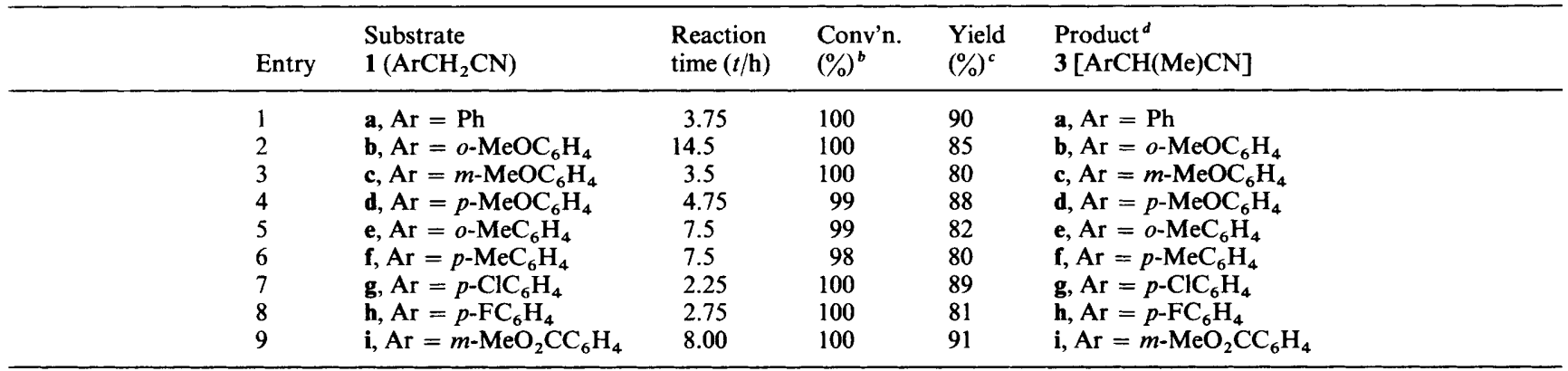

${ }^{a}$ All reactions were carried out in an autoclave at $180^{\circ} \mathrm{C}$. Substrate, DMC and $\mathrm{K}_{2} \mathrm{CO}_{3}$ in a 1:18:2 molar ratio. ${ }^{b}$ Conversions were determined by GC. ' All yields are based on distilled products. ${ }^{d}$ Selectivity in the monomethylated product was always $>99 \%$.

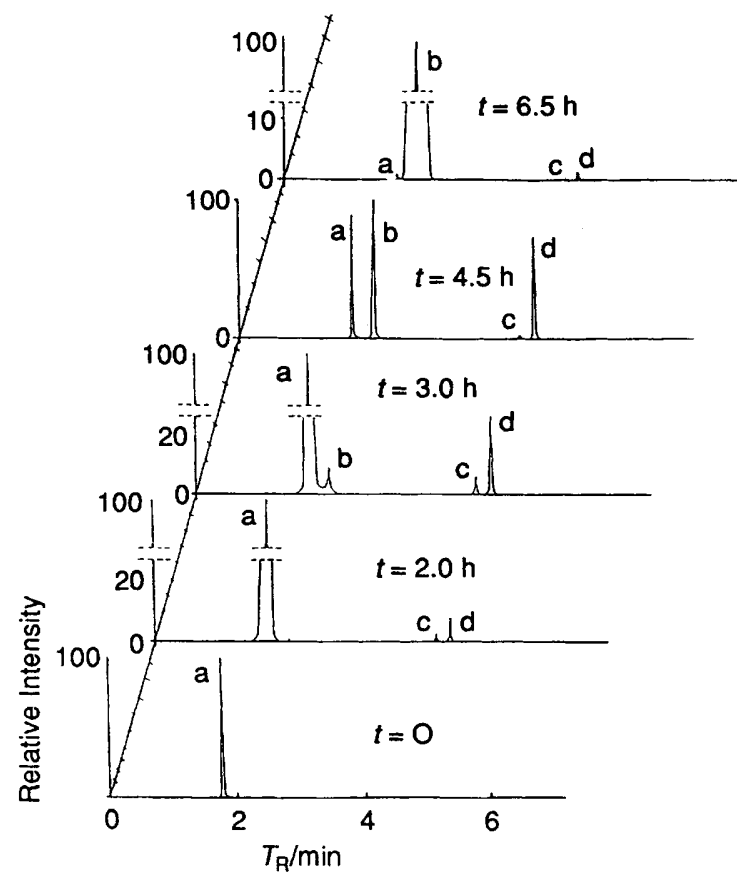

Fig. 1 The course of the reaction of $o$-tolylacetonitrile (1e) with DMC according to entry 5, Table 4. GC runs after reaction times $t$ of 2,3,4.5 and $6.5 \mathrm{~h}$ are reported. $\mathrm{a}=o-\mathrm{MeC}_{6} \mathrm{H}_{4} \mathrm{CH}_{2} \mathrm{CN} ; \mathrm{b}=o-\mathrm{MeC}_{6} \mathrm{H}_{4} \mathrm{CH}$ $(\mathrm{Me}) \mathrm{CN}, \quad \mathrm{c}=o-\mathrm{MeC}_{6} \mathrm{H}_{4} \mathrm{CH}\left(\mathrm{CO}_{2} \mathrm{Me}\right) \mathrm{CN}, \quad \mathrm{d}=o-\mathrm{MeC}_{6} \mathrm{H}_{4} \mathrm{C}(\mathrm{Me})-$ $\left(\mathrm{CO}_{2} \mathrm{Me}\right) \mathrm{CN}$.

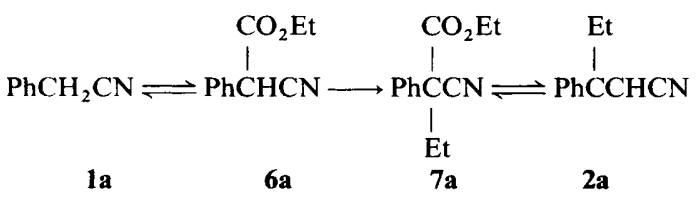

Scheme 1

concentration of the phenylacetonitrile 1a, initially formed by deethoxycarbonylation, rose to a maximum of $20 \%$ after $1 \mathrm{~h}$ and then after a further $2 \mathrm{~h}$ fell to zero. This resulted from formation of the intermediate $7 \mathbf{a}$, whose concentration reached a maximum (of $30 \%$ ) after $1.5 \mathrm{~h}$; after $4 \mathrm{~h}$, the starting material 6a was no longer present. The final reaction mixture consisted only of $7 \mathbf{a}$ and $2 \mathrm{a}$, conversion of the former into the latter requiring $18 \mathrm{~h}$ ( $22 \mathrm{~h}$ overall reaction time (see Scheme 1$)$.

In an independent reaction, when 7a was treated with DEC, 2a was formed very slowly ( $16 \%$ conversion after $15 \mathrm{~h}$, with no by-products, Scheme 1); however, operating in the presence of ethanol as a proton source $(10 \mathrm{~mol}$ equiv. with respect to substrate) the reaction proceeds faster, giving complete conversion after $3.5 \mathrm{~h}$.
Such results suggest that the conversion of $1 \mathrm{a}$ into $2 \mathrm{a}$ occurs through two equilibria and an ethylation process, the latter, being a non-equilibrium reaction, allowing complete transformation.

The methylation of 1 with DMC to give 3 also proceeds through two intermediates: $\operatorname{ArCH}\left(\mathrm{CO}_{2} \mathrm{Me}\right) \mathrm{CN}, 8$, and $\operatorname{ArC}(\mathrm{Me})\left(\mathrm{CO}_{2} \mathrm{Me}\right) \mathrm{CN}$ 9. Depending on the starting nitrile (see Table 4) the concentrations of 8 and 9 rose to a maximum (6$40 \%$ by GC analysis) and then fell to zero after complete conversion of 1 . The concentration of compound 9 was always higher than that of compound 8 , and, indeed, only in the reactions of compounds $1 \mathrm{e}$ and $1 \mathrm{i}$ with DMC (entries 5 and 9, Table 4) were compounds 8 detectable. Figs. 1 and 2 illustrate the course of such reactions. It seems likely that the slow reaction of $\mathbf{8}$ with DMC results from steric hindrance and the inductive effect, similar behaviour having been observed in the reaction of arylacetic esters with dialkyl carbonates. The reactions with DMC (see Table 6, entries 1-3) proceed via two intermediates (whose structures were confirmed by GC-MS): $\operatorname{ArCH}\left(\mathrm{CO}_{2} \mathrm{Me}\right)_{2}$ and $\operatorname{ArC}(\mathrm{Me})\left(\mathrm{CO}_{2} \mathrm{Me}\right)_{2}$.

The reaction of butan-4-olide with DMC (Table 5, entries 4-5) also proceeds via the corresponding $\alpha$-methoxycarbonyl and $\alpha$-methyl- $\alpha$-methoxycarbonyl derivatives. Moreover, the reaction of diethyl phenylmalonate with DEC at $200^{\circ} \mathrm{C}$ (entry 3 , Table 6) proceeded in a similar way to the reaction illustrated in Scheme 1: though the reaction time was longer, the same equilibria between the reagents and intermediates seemed to be involved.

\section{Discussion}

At complete conversion the selectivity observed in the alkylation of $\mathrm{ArCH}_{2} \mathrm{X}\left(\mathrm{X}=\mathrm{CN}, \mathrm{CO}_{2} \mathrm{Me}\right.$ ) with DMC (see Tables 4 and 5) is always $>99.5 \%$ in favour of the monomethylated product, even with a 20 molar excess of DMC as the reaction solvent. No comparison can be inferred from Table 1 between the previously reported results either of classical or PTCpromoted alkylation.

Such selectivity is not explicable in terms of $\mathrm{S}_{\mathrm{N}} 2$ displacement of the arylacetonitrile anion on DMC according to $\mathrm{a}_{\mathrm{Al}} 2$ mechanism, as it is with the methylation of phenols by DMC. ${ }^{6}$ The need for only a catalytic quantity of base (Table 2, entry 1 ), suggests that $\mathrm{MeOCO}_{2}{ }^{-}$is split into $\mathrm{CO}_{2}$ and $\mathrm{MeO}^{-}$, with regeneration of the base. Of the bases used, the most active were those in which a poor cation-anion interaction allowed 'naked' anion formation, a phenomenon well recorded under classical PTC conditions; ${ }^{14}$ the activity increases from lithium to cesium carbonate.

The results shown in Table 3 indicate that, in terms of reaction rates, DMC and DMF are comparable solvents for $\mathrm{S}_{\mathrm{N}} 2$ displacements, although with the latter, some dimethyl derivative $(10 \%)$ is also produced (entry 5$)$. 
Table 5 Reactions of DMC with arylacetic esters and butan-4-olide

\begin{tabular}{|c|c|c|c|c|c|c|c|}
\hline Entry & Substrate & $\begin{array}{l}\text { Temp. } \\
\left(T /{ }^{\circ} \mathrm{C}\right)\end{array}$ & $\begin{array}{l}\text { Reaction } \\
\text { time }(t / \mathrm{h})\end{array}$ & $\begin{array}{l}\text { Conv'n. } \\
(\%)\end{array}$ & $\begin{array}{l}\text { Selectivity } \\
(\%)^{b}\end{array}$ & $\begin{array}{l}\text { Yield } \\
(\%)\end{array}$ & Product \\
\hline $1^{a}$ & $\mathrm{PhCH}_{2} \mathrm{CO}_{2} \mathrm{Me}$ & 180 & 24 & 73 & $>99$ & $38^{c}$ & $\mathrm{PhCH}(\mathrm{Me}) \mathrm{CO}_{2} \mathrm{Me}$ \\
\hline $2^{a}$ & $\mathrm{PhCH}_{2} \mathrm{CO}_{2} \mathrm{Me}$ & 220 & 8 & 99 & 92 & $80^{d}$ & $\mathrm{PhCH}(\mathrm{Me}) \mathrm{CO}_{2} \mathrm{Me}^{e}$ \\
\hline $3^{a}$ & Methyl 6-methoxy-2-naphthylacetate & 220 & 6 & 100 & $>99$ & $90^{f}$ & Methyl 6-methoxy-2-naphthyl(methyl)acetate \\
\hline $4^{g}$ & Butan-4-olide & 210 & 6 & 100 & $93^{h}$ & $79^{d}$ & 2-Methylbutan-4-olide \\
\hline $5^{g}$ & Butan-4-olide & 220 & 5 & 100 & 76 & $76^{c}$ & 2-Methylbutan-4-olide \\
\hline
\end{tabular}

${ }^{a}$ Reaction carried out in an autoclave. Substrate, DMC and $\mathrm{K}_{2} \mathrm{CO}_{3}$ in a 1:18:2 molar ratio. ${ }^{b}$ Selectivity is defined as: [(mol of $\left.\mathrm{ArCH}(\mathrm{Me}) \mathrm{CO}_{2} \mathrm{Me}\right) /\left(\mathrm{mol}\right.$ of $\mathrm{ArCH}(\mathrm{Me}) \mathrm{CO}_{2} \mathrm{Me}+\mathrm{mol}$ of $\left.\left.\mathrm{ArC}(\mathrm{Me})_{2} \mathrm{CO}_{2} \mathrm{Me}\right)\right] \times 100$. ${ }^{\circ}$ Determined by GC. Entry 1: at the reported conversion, the reaction mixture consisted of $\mathrm{PhCH}(\mathrm{Me}) \mathrm{CO}_{2} \mathrm{Me}(35 \%)$ and $\mathrm{PhCH}\left(\mathrm{CO}_{2} \mathrm{Me}\right)_{2}(38 \%){ }^{d}$ Yields based on distilled products. ${ }^{e} \mathrm{Only} \mathrm{PhCH}-$ (Me) $\mathrm{CO}_{2} \mathrm{Me}$ and $\mathrm{PhC}(\mathrm{Me})_{2} \mathrm{CO}_{2} \mathrm{Me}$ were detected. ${ }^{f}$ Yield based on recrystallized product. ${ }^{g}$ Reaction carried out in an autoclave. Substrate, DMC and $\mathrm{K}_{2} \mathrm{CO}_{3}$ in a 1:5:1 molar ratio. ${ }^{h}$ At complete substrate conversion, reaction intermediates were still present (total amount $12 \%, \mathrm{GC}$ analysis).

Table 6 Reaction of DEC with arylacetonitriles and arylacetic esters ${ }^{a}$

\begin{tabular}{|c|c|c|c|c|c|}
\hline Entry & Substrate & $\begin{array}{l}\text { Temp. } \\
\left(T /{ }^{\circ} \mathrm{C}\right)\end{array}$ & $\begin{array}{l}\text { Reaction } \\
\text { time }(t / \mathrm{h})\end{array}$ & $\begin{array}{l}\text { Conv'n. } \\
(\%)\end{array}$ & Products $(\%)^{b}$ \\
\hline 1 & 1a $\mathrm{PhCH}_{2} \mathrm{CN}$ & 180 & 47.5 & 99 & $\mathrm{PhCH}(\mathrm{Et}) \mathrm{CN}(97) ; \mathrm{PhC}(\mathrm{Et})\left(\mathrm{CO}_{2} \mathrm{Et}\right) \mathrm{CN}(2)$ \\
\hline 2 & $\mathrm{PhCH}_{2} \mathrm{CO}_{2} \mathrm{Et}$ & 220 & 14.3 & 32 & $\mathrm{PhCH}(\mathrm{Et}) \mathrm{CO}_{2} \mathrm{Et}(12) ; \mathrm{PhCH}\left(\mathrm{CO}_{2} \mathrm{Et}\right)_{2}(2) ; \mathrm{PhC}(\mathrm{Et})\left(\mathrm{CO}_{2} \mathrm{Et}\right)_{2}(18)$ \\
\hline 3 & $\mathrm{PhCH}\left(\mathrm{CO}_{2} \mathrm{Et}\right)_{2}$ & 200 & 25.0 & 98 & $\mathrm{PhCH}(\mathrm{Et}) \mathrm{CO}_{2} \mathrm{Et}(18) ; \mathrm{PhCH}_{2} \mathrm{CO}_{2} \mathrm{Et}(43) ; \mathrm{PhC}(\mathrm{Et})\left(\mathrm{CO}_{2} \mathrm{Et}\right)_{2}(37)^{\mathrm{c}}$ \\
\hline
\end{tabular}

${ }^{a}$ All reactions carried out in autoclave. Substrate, $\mathrm{DEC}$ and $\mathrm{K}_{2} \mathrm{CO}_{3}$ in a 1:18:2 molar ratio. Other conditions as of Table 1 , entry $6 .{ }^{b} \mathrm{By}$ GC analysis. ${ }^{c}$ See Fig. 3.

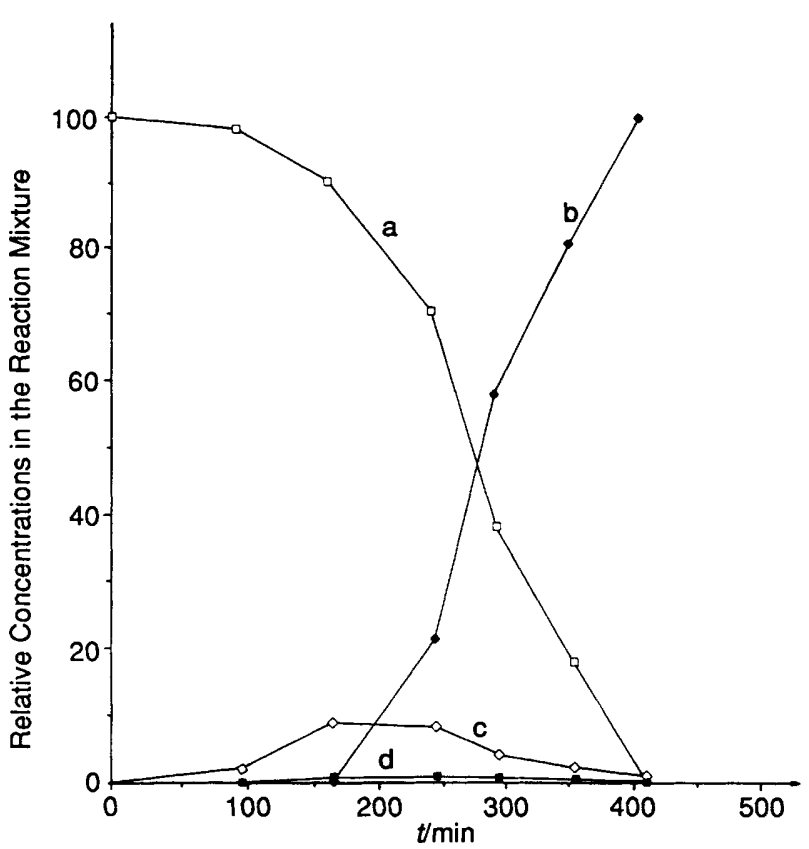

Fig. 2 The course of the reaction of $m$-(methoxycarbonyl)phenylacetonitrile 1i with DMC according to entry 9, Table 4: $a=m$ $\mathrm{MeO}_{2} \mathrm{CC}_{6} \mathrm{H}_{4} \mathrm{CH}_{2} \mathrm{CN} ; \mathrm{b}=m-\mathrm{MeO}_{2} \mathrm{CC}_{6} \mathrm{H}_{4} \mathrm{CH}(\mathrm{Me}) \mathrm{CN} ; \mathrm{c}=m-\mathrm{Me}-$ $\mathrm{O}_{2} \mathrm{CC}_{6} \mathrm{H}_{4} \mathrm{C}(\mathrm{Me})\left(\mathrm{CO}_{2} \mathrm{Me}\right) \mathrm{CN} ; \mathrm{d}=m-\mathrm{MeO}_{2} \mathrm{CC}_{6} \mathrm{H}_{4} \mathrm{CH}\left(\mathrm{CO}_{2} \mathrm{Me}\right) \mathrm{CN}$

Reactions in the presence of methanol as solvent (entry 3 ) or co-solvent (entry 4), produced no reaction intermediates and gave high selectivity. If iodomethane is present in either DMC or DMF (Table 3, entries 2 and 6, respectively) selectivity is much lower, a classical $S_{N} 2$ reaction between the corresponding anion of 2-phenylpropionitrile and MeI probably taking place to give results comparable to those of entries 1 and 2, Table 1.

A suggested reaction mechanism for the reactions illustrated in Scheme 1 is given in Scheme 2.

DMC has double reactivity: $(i)$ it is a methoxycarbonylating agent (reaction with the $\mathrm{ArCH}^{-} \mathrm{X}$ anion) according to a $\mathrm{B}_{\mathrm{Ac}} 2$ mechanism and (ii) it is a methylating agent [reactions with the

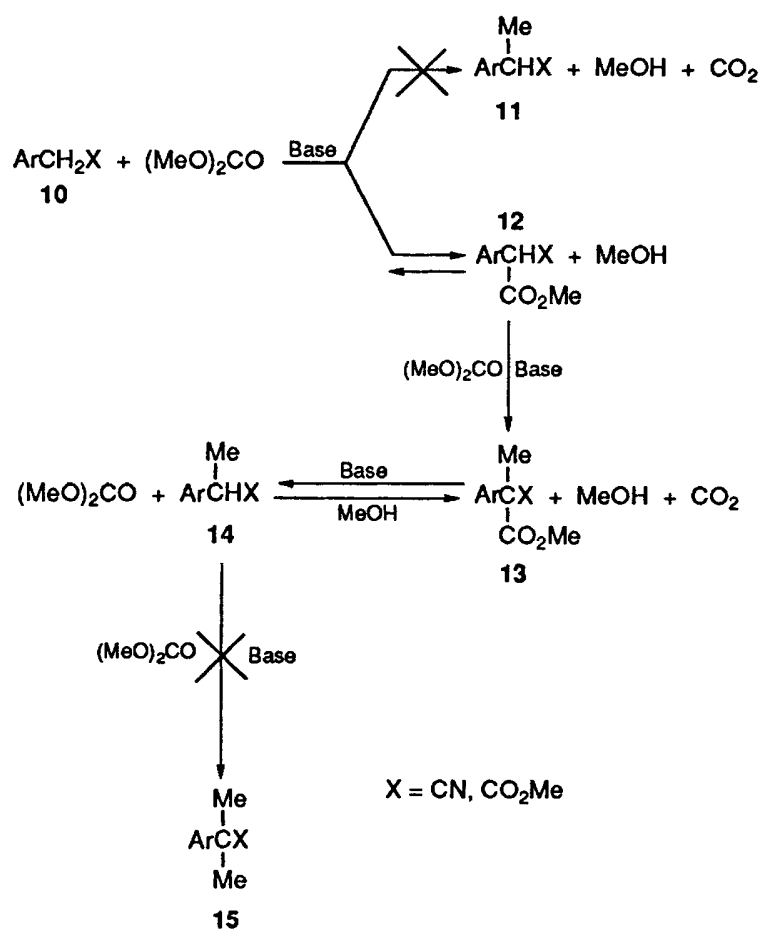

Scheme 2

$\operatorname{ArC}^{-}\left(\mathrm{CO}_{2} \mathrm{Me}\right) \mathrm{X}$ anion] according to a $\mathrm{B}_{\mathrm{A} 1} 2$ mechanism. Both reaction pathways are highly selective, since the methylation of the $\mathrm{ArCH}^{-} \mathrm{X}$ anions is very slow. This mechanism is evidenced by the fact that, when operating in the presence of iodomethane, the selectivity is lost (entries 2 and 6, Table 3).

The proposed mechanism also accounts for the fact that when methanol is co-solvent, the reaction is faster; this is because intermediate 13 reacts more rapidly.

Paradoxically, the factors which are expected to reduce selectivity (high temperature and an excess of the alkylating agent) instead promote it.

High temperatures allow a reaction pathway $\left(\mathrm{B}_{\mathrm{A} 1}{ }^{2}\right.$ mechanism) not otherwise detectable. ${ }^{15}$ 
DMC as solvent has been shown to provide a suitable polar and aprotic environment for selectively orientating the reactivity of $\mathrm{ArCH}^{-} \mathrm{X}$ toward methoxycarbonylation and $\mathrm{ArC}^{-}$ $\left(\mathrm{CO}_{2} \mathrm{Me}\right) \mathrm{X}$ towards methylation. Carbonates were the most effective base for the reaction, stronger ones (entries 6 and 7 , Table 2) decreasing the selectivity, possibly by improving anion activation.

Although high selectivity in these reactions results from optimization of the temperature, base, alkylating agent and solvent, further studies will, doubtless, clarify the role of each in promoting selective monomethylation. This, in turn, will allow the use of DMC in reactions with other substrates.

\section{Conclusions}

Arylacetonitriles and arylacetic esters have been shown to undergo highly selective monomethylation in a one-step process. This process demonstrates the use of a safe methylating reagent producing no by-products.

\section{Experimental}

General.-All the compounds used were ACS grade and were employed without further purification. The melting point of $\mathbf{1 6}$ was determined on a Buchi 535 melting point apparatus and is uncorrected. ${ }^{1} \mathrm{H}$ NMR spectra were recorded on a Varian EM $390(90 \mathrm{MHz})$ spectrometer using $\mathrm{CDCl}_{3}$ with tetramethylsilane as the internal standard. GC analyses were performed on a Varian GC 3300 using a $12 \mathrm{~m}$, DB1 capillary column. GC-MS analyses were performed on an HP 5971 mass detector at $70 \mathrm{eV}$ coupled to an HP 5890-Series II gas chromatograph fitted with a $30 \mathrm{~m}$, DB5 capillary column.

$p$-Fluorophenyl- and $o$ - and $p$-tolyl-acetonitriles were prepared from their respective benzyl chlorides under phasetransfer catalysis conditions, in toluene at $70^{\circ} \mathrm{C}$, according to established procedures. $^{17}$

Ethoxycarbonyl(phenyl)acetonitrile 6a.--Pieces of sodium $(2.0 \mathrm{~g}, 87 \mathrm{mmol})$ were treated with absolute ethanol $\left(46 \mathrm{~cm}^{3}\right)$, after which the excess of alcohol was first partially evaporated and then azeotropically removed by the addition and evaporation of anhydrous toluene $\left(10 \mathrm{~cm}^{3}\right)$. A mixture of phenylacetonitrile $(9.0 \mathrm{~g}, 0.077 \mathrm{~mol})$, diethyl carbonate $\left(35 \mathrm{~cm}^{3}\right.$, $0.29 \mathrm{~mol})$ and anhydrous toluene $\left(20 \mathrm{~cm}^{3}\right)$ was then added to the residue. During the reaction, anhydrous toluene $\left(c a .40 \mathrm{~cm}^{3}\right)$ was added dropwise to the mixture whilst, simultaneously, an equal amount was slowly distilled from the reaction flask. The mixture was heated under reflux for a further $2 \mathrm{~h}$, after which it was cooled to room temperature and treated slowly with dilute aqueous $\mathrm{HCl}\left(5 \%, 40 \mathrm{~cm}^{3}\right)$. The mixture was then extracted with diethyl ether $\left(3 \times 30 \mathrm{~cm}^{3}\right)$. The combined extracts were evaporated to provide a brown liquid which was then distilled in vacuo to give the title compound $6 \mathrm{a}(12.4 \mathrm{~g}, 84.7 \%)$ as a colourless liquid, b.p. $108-110^{\circ} \mathrm{C} / 0.3 \mathrm{mmHg}$ (lit., ${ }^{8} 125$ $\left.135^{\circ} \mathrm{C} / 3-5 \mathrm{mmHg}\right) ; \delta_{\mathrm{H}} 1.27\left(\mathrm{t}, 3 \mathrm{H}, \mathrm{CH}_{3}\right), 4.30\left(\mathrm{q}, 2 \mathrm{H}, \mathrm{CH}_{2}\right)$, $4.81(\mathrm{~s}, 1 \mathrm{H}, \mathrm{CH})$ and 7.16-7.73 (m, $5 \mathrm{H}, \mathrm{Ph}) ; \mathrm{m} / \mathrm{z} 189\left(\mathrm{M}^{+}\right.$, $2 \%$ ), $145(5), 118(9), 117(100), 116(55), 90(16), 89(22), 77(2)$, $63(9)$ and $51(3)$.

2-Ethoxycarbonyl-2-phenylbutyronitrile 7a.-With phenylacetonitrile $1 \mathrm{a}(9.0 \mathrm{~g}, 0.077 \mathrm{~mol})$ as the starting material, the preparation of 7a followed the procedure described for $6 \mathrm{a}$ with the following difference: after the reaction mixture had been heated under reflux for $2 \mathrm{~h}$, it was cooled to $85^{\circ} \mathrm{C}$ and treated with iodoethane $(15.6 \mathrm{~g}, 0.10 \mathrm{~mol})$; the reaction was complete in $4 \mathrm{~h}$. The reaction mixture was washed with water $\left(50 \mathrm{~cm}^{3}\right)$ and extracted with diethyl ether $\left(3 \times 30 \mathrm{~cm}^{3}\right)$. The combined extracts were evaporated and the liquid residue was distilled to give $7 \mathbf{a}\left(12.5 \mathrm{~g}, 75.5^{\circ}\right)$, b.p. $129-131^{\circ} \mathrm{C} / 0.25 \mathrm{mmHg}$ (lit., ${ }^{19 a}$ b.p. $\left.150^{\circ} \mathrm{C} / 10 \mathrm{mmHg}\right) ; \delta_{\mathrm{H}} 1.12\left(\mathrm{t}, 3 \mathrm{H}, \mathrm{CH}_{3}\right), 1.26\left(\mathrm{t}, 3 \mathrm{H}, \mathrm{CH}_{3}\right)$, 2.00-2.76 (m, $\left.2 \mathrm{H}, \mathrm{CH}_{2}\right), 4.43\left(\mathrm{q}, 2 \mathrm{H}, \mathrm{CH}_{2}\right)$ and 7.50-8.08 (m, $5 \mathrm{H}, \mathrm{Ph})$.

Solubility of a Variety of Alkaline Carbonates in Dimethyl Carbonate $(D M C)$ at $180^{\circ} \mathrm{C}$ (Table 2).-A mixture of DMC $\left(100 \mathrm{~cm}^{3}\right)$ and each carbonate $\mathrm{M}_{2} \mathrm{CO}_{3}(\mathrm{M}=\mathrm{Li}, \mathrm{Na}, \mathrm{K}, \mathrm{Cs})$ in 11:1 molar ratio, respectively, was heated and magnetically stirred in a stainless-steel autoclave (described below) at $180^{\circ} \mathrm{C}$. After $1 \mathrm{~h}$, agitation was stopped and $5-\mathrm{cm}^{3}$ samples were taken every 25-30 min until the concentration of $\mathrm{M}_{2} \mathrm{CO}_{3}$ in DMC was constant. This value was determined by titrating each sample against aqueous sulfuric acid $\left(0.018 \mathrm{~mol} \mathrm{dm}^{-3}\right)$ with Bengal Rose B as indicator. Because of the insolubility of DMC in water, an equal amount of absolute methanol $\left(5 \mathrm{~cm}^{3}\right)$ was added to each sample before titration. A correction to the measured alkalinity was made by comparing it with a standard solution of DMC $\left(5 \mathrm{~cm}^{3}\right)$ in methanol $\left(5 \mathrm{~cm}^{3}\right)$.

Reactions Carried Out in an Autoclave: General Procedure (Tables 1-6).--All reactions were carried out in a stainless-steel (AISI 316) autoclave (internal volume $250 \mathrm{~cm}^{3}$ ), equipped with a purging valve, through which, at room temperature, air was removed before each reaction by purging with a $\mathrm{N}_{2}$ stream. A magnetically stirred mixture of the alkylating agent, arylacetonitrile and base in the reported molar ratio (see Tables 1-5) was heated in the autoclave, itself heated in an electrical oven, at $180^{\circ} \mathrm{C}$. A thermocouple and a needle valve were fixed onto the autoclave head, the former dipping into the reaction mixture and the latter connected to $a \frac{1}{8}$ in ${ }^{*}$ stainless-steel suction pipe which, in turn, was immersed into the reaction mixture. In this way it was possible to extract samples (analysed by GC) during the course of the reactions.

All the mono-methylated compounds, except for Naproxen 16, were purified by distillation in a micro-Claisen distillation apparatus with a fused-on Liebig condenser. They were all colourless liquids and their purity was $>99 \%$ (by GC), unless otherwise noted

2-Phenylpropionitrile 3a. Starting from phenylacetonitrile 1a $(5.0 \mathrm{~g})$, after distillation, 3a $(5.0 \mathrm{~g}, 90 \%)$ was obtained, b.p. $62-64^{\circ} \mathrm{C} / 0.25 \mathrm{mmHg}$ (lit., ${ }^{20}$ b.p. $74^{\circ} \mathrm{C} / 0.5 \mathrm{mmHg}$ ); $\delta_{\mathrm{H}} 1.62$ $\left(\mathrm{d}, 3 \mathrm{H}, \mathrm{CH}_{3}\right), 3.92(\mathrm{q}, 1 \mathrm{H}, \mathrm{CH})$ and $7.45(\mathrm{~s}, 5 \mathrm{H}, \mathrm{Ph}) ; \mathrm{m} / z 131$ $\left(\mathrm{M}^{+}, 33 \%\right), 117(9), 116(100), 89(11), 77(8), 63(6)$ and $51(11)$.

2-(o-Methoxyphenyl)propionitrile 3b. Starting from o-methoxyphenylacetonitrile $1 \mathrm{~b}(4.0 \mathrm{~g})$, after distillation, $3 \mathrm{~b}^{21}(3.7 \mathrm{~g}$, $85 \%$ ) was obtained, b.p. $79-82^{\circ} \mathrm{C} / 0.25 \mathrm{mmHg} ; \delta_{\mathrm{H}} 1.56(\mathrm{~d}, 3 \mathrm{H}$, $\left.\mathrm{CH}_{3}\right), 3.92\left(\mathrm{~s}, 3 \mathrm{H}, \mathrm{CH}_{3}\right), 4.30(\mathrm{q}, 1 \mathrm{H}, \mathrm{CH})$ and $7.00-7.62(\mathrm{~m}$, $4 \mathrm{H}, \mathrm{Ph})$.

2-(m-Methoxyphenyl)propionitrile 3c. Starting from $m$-methoxyphenylacetonitrile $1 \mathrm{c}(4.0 \mathrm{~g})$, after distillation, $3 \mathrm{c}^{22}(3.5 \mathrm{~g}$, $80 \%$ ) was obtained, b.p. $89-91^{\circ} \mathrm{C} / 0.15 \mathrm{mmHg} ; \delta_{\mathrm{H}} 1.62(\mathrm{~d}, 3 \mathrm{H}$, $\left.\mathrm{CH}_{3}\right), 3.85\left(\mathrm{~s}, 3 \mathrm{H}, \mathrm{CH}_{3}\right), 3.88(\mathrm{q}, 1 \mathrm{H}, \mathrm{CH})$ and $6.85-7.43(\mathrm{~m}$, $4 \mathrm{H}, \mathrm{Ph})$.

2-(p-Methoxyphenyl)propionitrile 3d. Starting from p-methoxyphenylacetonitrile $1 \mathrm{~d}(4.0 \mathrm{~g})$, after distillation, $\mathbf{3 d}^{23}(3.9 \mathrm{~g}$, $88 \%$ ) was obtained, b.p. $90-92^{\circ} \mathrm{C} / 0.20 \mathrm{mmHg} ; \delta_{\mathrm{H}} 1.57(\mathrm{~d}, 3 \mathrm{H}$, $\left.\mathrm{CH}_{3}\right), 3.85\left(\mathrm{~s}, 3 \mathrm{H}, \mathrm{CH}_{3}\right), 3.89(\mathrm{q}, 1 \mathrm{H}, \mathrm{CH})$ and $6.97-7.43(\mathrm{~m}$, $4 \mathrm{H}, \mathrm{Ph})$.

2-(o-Tolyl)propionitrile 3e. Starting from o-tolylacetonitrile 1e $(3.0 \mathrm{~g})$, after distillation, $3 \mathrm{e}^{23.24}(2.7 \mathrm{~g}, 82 \%)$ was obtained, b.p. $90-92^{\circ} \mathrm{C} / 0.20 \mathrm{mmHg}$ (lit., ${ }^{24 a}$ b.p. $95-97^{\circ} \mathrm{C} / 0.20 \mathrm{mmHg}$ ); $\delta_{\mathrm{H}} 1.53\left(\mathrm{~d}, 3 \mathrm{H}, \mathrm{CH}_{3}\right), 2.30\left(\mathrm{~s}, 3 \mathrm{H}, \mathrm{CH}_{3}\right), 3.95(\mathrm{q}, 1 \mathrm{H}, \mathrm{CH})$ and 6.88-7.52 (m, $4 \mathrm{H}, \mathrm{Ph})$.

2-(p-Tolyl)propionitrile 3f. Starting from p-tolylacetonitrile If ( $3.0 \mathrm{~g})$, after distillation, $3 \mathrm{f}(2.6 \mathrm{~g}, 80 \%)$ was obtained, b.p.

\footnotetext{
$* 1$ inch $=2.54 \mathrm{~cm}$
} 
$70-72{ }^{\circ} \mathrm{C} / 0.45 \mathrm{mmHg}$ (lit., ${ }^{25 a}$ b.p. $123^{\circ} \mathrm{C} / 12 \mathrm{mmHg}$ ); $\delta_{\mathrm{H}} 1.59$ (d, $\left.3 \mathrm{H}, \mathrm{CH}_{3}\right), 2.33\left(\mathrm{~s}, 3 \mathrm{H}, \mathrm{CH}_{3}\right), 3.83(\mathrm{q}, 1 \mathrm{H}, \mathrm{CH})$ and $7.14-7.25$ $(\mathrm{m}, 4 \mathrm{H}, \mathrm{Ph})$.

2-(p-Chlorophenyl)propionitrile 3g. Starting from p-chlorophenylacetonitrile $1 \mathrm{~g}(5.0 \mathrm{~g})$, after distillation, $3 \mathrm{~g}^{23,26}(4.9 \mathrm{~g}$, $89 \%$ ) was obtained, b.p. $83-86^{\circ} \mathrm{C} / 0.45 \mathrm{mmHg}$ (lit., ${ }^{26 a}$ b.p. 84 $\left.86^{\circ} \mathrm{C} / 0.45 \mathrm{mmHg}\right) ; \delta_{\mathrm{H}} 1.61\left(\mathrm{~d}, 3 \mathrm{H}, \mathrm{CH}_{3}\right), 3.88(\mathrm{q}, 1 \mathrm{H}, \mathrm{CH})$ and 7.25-7.36 (m, $4 \mathrm{H}, \mathrm{Ph})$.

2-(p-Fluorophenyl)propionitrile 3h. Starting from p-fluorophenylacetonitrile $1 \mathrm{~h}(3.0 \mathrm{~g})$, after distillation, $3 \mathrm{~h}^{23,26}(2.7 \mathrm{~g}$, $81 \%$ ) was obtained, b.p. $77-78^{\circ} \mathrm{C} / 0.5 \mathrm{mmHg} ; \delta_{\mathrm{H}} 1.63(\mathrm{~d}, 3 \mathrm{H}$, $\left.\mathrm{CH}_{3}\right), 3.89(\mathrm{q}, 1 \mathrm{H}, \mathrm{CH})$ and $7.00-7.38(\mathrm{~m}, 4 \mathrm{H}, \mathrm{Ph})$.

2-(m-Methoxycarbonylphenyl)propionitrile 3i. Starting from $m$-methoxycarbonylphenylacetonitrile $1 \mathrm{i}(10.0 \mathrm{~g})$, after distillation, $3 \mathrm{i}(9.9 \mathrm{~g}, 91 \%)$ was obtained, b.p. $109-110^{\circ} \mathrm{C} / 0.8 \mathrm{mmHg}$ (Found: C, 69.8; H, 5.9; N, 7.4. Calc. for $\mathrm{C}_{11} \mathrm{H}_{11} \mathrm{NO}_{2}$ : C, 69.83; $\mathrm{H}, 5.86 ; \mathrm{N}, 7.40 \%) ; \delta_{\mathrm{H}} 1.66\left(\mathrm{~d}, 3 \mathrm{H}, \mathrm{CH}_{3}\right), 3.98\left(\mathrm{~s}, 3 \mathrm{H}, \mathrm{CH}_{3}\right)$, 3.88-4.13 (q, $1 \mathrm{H}, \mathrm{CH})$ and 7.51-8.12 (m, $4 \mathrm{H}, \mathrm{Ph})$.

Methyl 2-phenylpropionate 5a. Starting from methyl phenylacetate $(5.0 \mathrm{~g})$, after distillation, $5 \mathrm{a}(4.4 \mathrm{~g}, 80 \%)$ was obtained, b.p. $78-81^{\circ} \mathrm{C} / 0.5 \mathrm{mmHg}$ (lit., ${ }^{25 b}$ b.p. $119^{\circ} \mathrm{C} / 22 \mathrm{mmHg}$ ); $\delta_{\mathrm{H}}$ $1.60\left(\mathrm{~d}, 3 \mathrm{H}, \mathrm{CH}_{3}\right), 3.75$ (s, $\left.3 \mathrm{H}, \mathrm{CH}_{3}\right), 3.58-3.93(\mathrm{q}, 1 \mathrm{H}, \mathrm{CH})$ and $7.3(\mathrm{~m}, 5 \mathrm{H}, \mathrm{Ph})$.

2-(6-Methoxy-2-naphthyl)propionic acid (racemic Naproxen) 16. Starting from methyl 6-methoxy-2-naphthylacetate $(5.0 \mathrm{~g})$, after the reaction, $\mathrm{K}_{2} \mathrm{CO}_{3}$ was filtered off and dimethyl carbonate removed from the filtrate under reduced pressure. The solid residue methyl 2-(6-methoxy-2-naphthyl)propionate was treated with aq. $\mathrm{NaOH}\left(10 \%, 20 \mathrm{~cm}^{3}\right)$ and the mixture was heated and stirred, under reflux, for $8 \mathrm{~h}$. After the mixture had cooled to room temperature, aq. $\mathrm{HCl}\left(15 \% ; 10 \mathrm{~cm}^{3}\right)$ was carefully added to it. The precipitated solid was filtered off and recrystallized from hexane-acetone $(9: 1 \mathrm{v} / \mathrm{v})$ to give racemic Naproxen 16 (4.5 g, $90 \%$; purity $96 \%$ by GC), m.p. 153.2 $154.6^{\circ} \mathrm{C}$ (lit., ${ }^{25 \mathrm{c}} \mathrm{m}$.p. $\left.150-151^{\circ} \mathrm{C}\right) ; \delta_{\mathrm{H}} 1.60\left(\mathrm{~d}, 3 \mathrm{H}, \mathrm{CH}_{3}\right), 3.81-$ $4.07(\mathrm{q}, 1 \mathrm{H}, \mathrm{CH}), 3.95\left(\mathrm{~s}, 3 \mathrm{H}, \mathrm{CH}_{3}\right)$ and $7.12-8.13(\mathrm{~m}, 6 \mathrm{H}$, naphthyl).

2-Methylbutan-4-olide. Starting from butan-4-olide $(7.0 \mathrm{~g})$, after distillation, 2-methylbutan-4-olide ${ }^{27}(6.4 \mathrm{~g}$; purity $85 \%$ by GC) was obtained, b.p. $64-67^{\circ} \mathrm{C} / 0.65 \mathrm{mmHg}$.

\section{Acknowledgements}

This work was supported by Tessenderlo Chemie, (Tessenderlo, Belgium). Dr. Gabriele Breviglieri of Farchemia S.r.1. (Treviglio, Italy), is also gratefully acknowledged.

\section{References}

1 W. Carruthers, Some Modern Synthetic Methods of Organic Synthesis, 3rd edn., Cambridge University Press, Cambridge, 1989.

2 J. P. Rieu, A. Boucherle, H. Cousse and G. Mouzin, Tetrahedron, 1986, 42, 4095 .

3 (a) C. M. Starks and C. Liotta, Phase-Transfer Catalysis, Academic Press Inc., New York, 1976, ch. 5, pp. 170-196; (b) E. V. Dehmlov and
S. S. Dehmlov, Phase-Transfer Catalysis, Verlag Chemie, Weinheim, 1983, ch. 3, pp. 123-133.

4 (a) P. Tundo, G. Moraglio and F. Trotta, Ind. Eng. Chem. Res., 1989, 28,$881 ;($ b) P. Tundo, Continuous Flow Methods in Organic Synthesis, E. Horwood, Ltd., Chichester, UK, 1991.

5 P. Tundo, J. Org. Chem., 1979, 44, 2048.

6 P. Tundo, F. Trotta, G. Moraglio and F. Ligorati, Ind. Eng. Chem. Res., 1988, 28, 1565.

7 (a) M. Lissel, S. Schmidt and B. Neumann, Synthesis, 1986, 382; (b) F. Trotta, P. Tundo and G. Moraglio, J. Org. Chem., 1987, 52, 1300.

8 (a) E. Angeletti, F. Trotta, P. Tundo and P. Venturello, Eur. Pat. 0240 863, USP 4894 471; (b) P. Tundo, F. Trotta and G. Moraglio, J. Chem. Soc., Perkin Trans. 1, 1989, 1070.

9 U. Romano, R. Tesei, M. Massi Mauri and P. Rebora, Ind. Eng. Chem. Prod. Res. Dev., 1980, 19, 396.

10 A. Brändström and U. Junggren, Tetrahedron Lett., 1972, 472.

11 M. Mikolajczyk, S. Grzejszczak, A. Zatorski, F. Montanari and M. Cinquini, Tetrahedron Lett., 1975, 3757.

12 R. Schwesinger, Nachr. Chem. Tec. Lab., 1990, 38, 1214.

13 P. Loosen, P. Tundo and M. Selva, It P MI92A00081/1992.

14 F. Montanari, D. Landini and F. Rolla, Top. Curr. Chem., 1982, 101 , 147.

15 (a) V. H. Wallingford A. M. Homeyer and D. M. Jones, J. Am Chem Soc., 1941, 63, 2056; (b) A. Philip and F. I. Carroll, Org. Prep. Proced. Int., 1975, 7, 117; (c) M. Alderdice, F. W. Sum and L. Weiler, Org. Synth., 1984, 62, 14

16 P. Loosen, P. Tundo and M. Selva, USP Appl. 922140/1992; Jap P Appl. 4-223302/1992.

17 C. M. Starks, J. Am. Chem. Soc., 1971, 93, 195.

18 E. C. Horning, A. F. Finelli, Org. Synth., Coll. Vol. IV, Wiley, New York, 1967, pp. 461-463

19 (a) R. Ketari and A. Foucaud, J. Org. Chem., 1981, 46, 4498; (b) J. S. Chamberlain, J. J. Chap, J. E. Doyle and L. B. Spaulding, J. Am. Chem. Soc., 1935, 57, 352; (c) A. S. Vitvitskaya, F. B. Naidis, E. Z. Katsnel'son and I. A. Karpinskaya, Khim. Farm. Zh., 1981, 15, 85-88; Chem. Abstr., 1981, 95, 168739h.

20 I. Angres and H. E. Zieger, J. Org. Chem., 1975, 40, 1457.

21 C. Gervais, D. Anker, M. Chareire and H. Pacheco, Bull. Soc. Chim. Fr., 1979, 5, 241 .

22 (a) H. Kugita and T. Oine, Chem. Pharm. Bull., 1963, 11, 253; (b) A. Cheng, E. Uyeno, W. Polgar, L. Toll, J. A. Lawson, J. I. DeGraw, G. Loew, A. Camerman and N. Camerman, J. Med. Chem., 1986, 29, 531 .

23 (a) R. W. Freerksen, S. J. Selikson, R. R. Wroble, K. S. Kyler and D. S. Watt, J. Org. Chem., 1983, 48, 4087; (b) M. Lemarie, J. Doussot and A. Guy, Chem. Lett., 1988, 10, 1581 .

24 (a) G. A. Pinna, M. Loriga, G. Paglietti and G. Cignarella Farmaco Ed. Sci., 1980, 35, 684; (b) M. S. Gibson, J. Chem. Soc., $1956,808$.

25 Dictionary of Organic Compounds, 5th edn., Chapman and Hall, New York, 1982, (a) vol.4, p. 4006; (b) vol. 5, p. 4662; (c) vol. 4, p. 4181. 26 (a) H. Miyamatsu, S. Ueno, M. Shimizu, J. Hoson, M. Tomari, K. Seida, T. Suzuki and J. Wada, J. Med. Chem., 1974, 17, 491; (b) D. S. Watt, J. Org. Chem., 1974, 39, 2799; (c) J. Heeres, L. J. J. Backx and J. M. Van Cutsem, J. Med. Chem., 1976, 19, 1148.

27 Y. Ishi, K. Osakada, M. Ikariya, S. Sahuri and S. Yoshikawa, J. Org. Chem., 1986, 51, 2034.
Paper 3/07287H

Received 9th December 1993 Accepted 19th January 1994 